\title{
Piauí é aqui: As pinturas rupestres piauienses entre a Arqueologia e a História da Arte
}

\section{MANOEL SILVESTRE FRIQUES}

\section{Resumo}

$\mathrm{O}$ artigo coteja as pinturas rupestres piauienses com algumas interpretações das imagens pré-históricas desenvolvidas no âmbito da História da Arte. Para isso, recupera o sistema taxonômico elaborado por Niède Guidon $(1985 ; 1989)$, observando aí a presença de algumas noções postas à prova pela produção artística moderna e contemporânea. $\mathrm{O}$ questionamento do enquadramento convencional da História da Arte motiva também uma reconsideração do conceito de arte a partir dos registros rupestres piauienses. Por fim, frente à inadequação dos pares conceituais encontrados na área em especial, a oposição entre naturalismo e geometrismo - propõe-se uma leitura das imagens piauienses enquanto escrituras multinaturalistas, conforme a noção concebida por Eduardo Viveiros de Castro (2015).

Palavras-chave: História da arte, pinturas rupestres, Parque Nacional Serra da Capivara 


\section{Piauí is here: Brazilian's cave paintings between Archeology and Art History}

\section{MANOEL SILVESTRE FRIQUES}

\section{Abstract}

The article contrasts Piaui's rock paintings with some interpretations of the prehistoric images found within the context of the History of Art. To that end, it recovers the taxonomic system elaborated by Niède Guidon, observing the presence of some notions put to the test by the modern and contemporary artistic production. The questioning of History of Art conventional framework also motivates a reconsideration of the concept of art from the Piauí rupestrian records. Finally, regarding the inadequacy of conceptual pairs found in the area - especially the

Keywords: Art History, rock paintings, Serra da Capivara National Park opposition between naturalism and geometrism - it is proposed a reading of Piauí images as multinaturalist writings, according to the notion conceived by Eduardo Viveiros de Castro (2015). 


\section{Piauí es aquí: Las pinturas rupestres brasileñas entre la Arqueología y la Historia del Arte}

\section{MANOEL SILVESTRE FRIQUES}

\section{Resumen}

El artículo compara las pinturas rupestres piauienses con algunas interpretaciones de las imágenes prehistóricas desarrolladas en el ámbito de la historia del arte. Para eso, recupera el sistema taxonómico elaborado por Niède Guidon $(1985 ; 1989)$, observando allí la presencia de algunas nociones puestas a prueba por la producción artística moderna y contemporánea. El cuestionamiento del encuadramiento convencional de la historia del arte produce también una reconsideración del concepto de arte a partir de los registros rupestres piauienses. Por último, frente a la inadecuación de los pares conceptuales encontrados en el área - en especial, la oposición entre naturalismo y geometrismo - se propone una lectura de las imágenes piauienses como escrituras multinaturalistas, según la noción concebida por Eduardo Viveiros de Castro.
Palabras clave:

Historia del arte, pinturas rupestres, Parque Nacional Serra da Capivara 
"O rastro não é somente a desaparição da origem, ele quer dizer aqui no discurso que proferimos e segundo o percurso que seguimos que a origem não desapareceu sequer, que ela jamais foi retroconstituída a não ser por uma não-origem, o rastro, que se torna, assim, a origem da origem."

(Jacques Derrida)

"Os animais também são humanos. [...] Damos a eles o nome de caça, mas of fato é que somos todos humanos. Assim é."

(Davi Kopenawa)

O objeto deste ensaio são as primeiras imagens de que se tem notícia no Brasil: as inscrições rupestres piauienses. Não que haja uma certeza absoluta quanto ao pioneirismo, seja do homem na América do Sul, seja das imagens ali registradas. Tanto nacional quanto internacionalmente, os grafismos encontrados no Nordeste brasileiro estão envoltos em dissensos, descrenças e desconfianças. Aqui, serão consideradas as pinturas rupestres do Parque Nacional Serra da Capivara, Patrimônio Mundial da Unesco onde se encontra a maior concentração por quilômetro quadrado de registros sobre rochas do mundo, lidas também como a origem da arte indígena brasileira.

Em âmbito internacional, há um fervoroso debate nos círculos científicos arqueológicos para saber qual das Américas detém a dianteira da presença humana, mesmo que tenha sido o último dos continentes onde o homo sapiens tenha pisado (a África é o berço indiscutível da humanidade). Grosso modo, as diversas linhas especulativas se organizam 
em duas perspectivas antagônicas. Por um lado, há o entendimento relativamente hegemônico promovido pela escola estadunidense - baseado em rastros arqueológicos indeléveis - a partir das descobertas casadas de vestígios de fósseis de animais e de instrumentos de caça nas cidades de Folsom e Clóvis (Novo México). Os indícios reforçam a teoria segundo a qual o povoamento das Américas havia se dado por meio da passagem de grupos provenientes da Sibéria pelo estreito de Bering, tendo chegado à costa ocidental da América do Norte há aproximadamente 15 mil anos. Deixando de lado todos os demais rastros encontrados nas demais Américas, esta teoria prescreve o pioneirismo da presença humana no território estadunidense.

É bastante sintomática a proximidade - histórica e argumentativa - entre a determinação por reconhecer em seu território a prevalência da existência humana no continente e a valorização dos Estados Unidos da América enquanto centro irradiador da arte moderna. Isto é, o argumento arqueológico é, de certo modo, análogo ao argumento historiográfico e crítico da arte: ambos reforçam este país enquanto locus da avant-garde, seja da humanidade, seja da arte. A analogia aqui sugerida só se reforça quando se observa que a preocupação formal está presente em ambas as argumentações: tanto na perspectiva historiográfico-institucional hegemônica nos Estados Unidos, emblematizada pelo Museu de Arte Moderna de Nova Iorque (MoMA), quanto nos movimentos abstratos como o Expressionismo Abstrato de Jackson Pollock e David Smith, e também pelas "escolas" críticas formalistas, em especial a de Clement Greenberg e de seus oblíquos conservadores, Rosalind Krauss e Yve-Alain Bois. Do ponto de vista arqueológico, a hipótese "Clovis First" baseia-se em um perfeito casamento entre forma e função, sendo a Gestalt de determinados artefatos um dos fatores (apenas um: o debate se baseia em sondagens científicas - como os testes por carbono $14 \mathrm{e}$ por termoluminescência - e outras evidências, como a proximidade entre os instrumentos e os fósseis de animais) que levam os cientistas a ver na América do Norte os primeiros traços da ocupação humana. Em suma, arrisca-se a dizer que a teoria "Clovis First" é análoga à "Pollock first", resultando esta equação, inequivocamente, em "EUA first" (ou "America First", diria Donald Trump).

Em contraste a isso, há a perspectiva de Niède Guidon, fundadora da Fundação Museu do Homem Americano (Fumdham), em São Raimundo Nonato ${ }^{1}(\mathrm{PI})$, e guardiã incansá- 
vel do tesouro rupestre brasileiro. Suas pesquisas remontam a 1970, quando foi formada uma equipe franco-brasileira de modo a contornar a nossa "principiante pré-história" com a investigação da rica "densidade de sítios pré-históricos e cronologias muito antigas" (MARTIN, 1997, p. 7), resultando daí uma poderosa base para as pesquisas subsequentes. A partir de escavações sistemáticas seguidas de sondagens científicas variadas, esta equipe encontrou, em sítios arqueológicos do sudeste piauiense, registros rupestres, artefatos de pedra lascada, evidências de fogueiras estruturadas, entre outros vestígios da cultura material e imaterial que permitiram o desenvolvimento de uma teoria alternativa da ocupação humana nas Américas. Os resultados científicos destes achados sugerem que a ocupação remonta há cerca de 100 mil anos, pondo por terra a hipótese de os homens terem passado pelo estreito de Bering, mas pelo Atlântico. Aqui, forma e função não são mutuamente confirmatórias. Melhor dizendo: na ausência inquestionável da prova formal, recorre-se a outros meios de comprovação que confirmem as respectivas funções dos vestígios encontrados. Esses indícios vêm se somar a tantos outros na América Latina, conforme sintetiza Gabriela Martin do seguinte modo:

Desde Nennana, no Alasca, até Monte Verde no sul do Chile, há evidência de ocupação humana anteriores a 15-20 mil anos nas Américas, em uns 80 sítios que os arqueólogos norte-americanos chamam evidências pré-Clóvis ou pré-Folsom [...] Não se pode ignorar o NE na hora de se discutir a antiguidade do homem na América e as vias de dispersão por ele percorridas, não importando se foi há 20, 30 ou 40 mil anos [...] É conhecida de todos a longa sequência estratigráfica lograda no Sítio do Boqueirão da Pedra Furada que pode significar a permanência do homem pré-histórico nesse sítio a partir de 48 mil anos (MARTIN, 1997, p. 10).

Mencionar a luta de Guidon é também deslocar a perspectiva da querela internacional ao contexto brasileiro. Aqui, o debate não é meramente arqueológico, adquirindo matizes político-institucionais, uma vez que os esforços de Guidon e sua equipe sofrem, intermitentemente, o risco de desaparecimento. A condição precária dos rastros pré-históricos se alastra, com isso, para a própria infraestrutura científico-institucional responsável por suas pesquisa e conservação, reforçando o descaso crônico e congênito que caracteriza a 
governança de nosso país. Nesse sentido, há também uma forte analogia com o campo da arte brasileira, visto que, entre os nossos mais reconhecidos críticos, é de relativo consenso a condição frágil (NAVES, 1996, p. 11), modesta (NAVES, 2007, p. 215), fantasmática (BRITO, 2013, p. 27), fraturada (SCOVI$\mathrm{NO}, 2015, \mathrm{p} .36$ ), quase inexistente (VENANCIO FILHO, 2013, p. 7) de nossa história (e nossa historiografia) da arte. Assim, a (história da) arte e a arqueologia brasileiras são irmãs, em termos institucionais e epistemológicos, ${ }^{2}$ dados seus respectivos processos de lacunas e desestruturação: tudo ainda é construção e já é ruína. Isto é um fato, não é algo sobre o que se deve especular. Desenvolvemos nossas especulações em outra direção, não sem antes compreender outro conflito: as abordagens interpretativas dos grafismos rupestres brasileiros.

\section{O cientificismo e o pavor do subjetivismo}

Muitos pesquisadores já se dedicaram ao enigma das pinturas rupestres nordestinas utilizando-se de variadas ferramentas analíticas. Esquematicamente, pode-se dizer, com Anne-Marie Pessis, que estes esforços agrupam-se em dois tipos de abordagens, uma pré-científica (ou clássica) e outra científica (ou arqueológica):

A primeira considera as pinturas e gravuras rupestres como um objeto de estudo em si, ao invés que a segunda considera as pinturas rupestres como uma fonte de dados de pesquisa em pré-história, e portanto sua análise está estreitamente ligada ao conjunto da pesquisa arqueológica (PESSIS, 1993, p. 8).

Desenvolvida a partir das descobertas das cavernas europeias encontradas na zona franco-cantábrica (Lascaux, Altamira, Montignac, Polignac etc.), a abordagem clássica foi dominante até a década de 80 , aproximando-se dos registros rupestres munida de categorias estéticas. Prevalecem aqui os critérios morfológicos que permitem ao observador justapor registros rupestres de contextos geográficos distintos na "dominância da atemporalidade" (PESSIS, 1993, p. 8). Apesar de bastante detalhistas e minuciosos, tais estudos conduzem também a conclusões questionáveis, como aquelas realizadas por Arnold Hauser (2000) ou Wilhelm Worringer (1997), que tratam de estabelecer equivalências esquemáticas e aparentemente indiscutíveis entre os "estilos" rupestres (em geral, dois, organizados enquanto par opositivo: o naturalista ver- 
sus o geométrico) e, respectivamente, a idade da ocupação humana (o paleolítico e o neolítico) e a relação com o espaço circundante (a presença ou não de empatia em relação ao meio). Pessis (1993) ressalta ainda que a abordagem clássica considera os vestígios rupestres enquanto produtos finais, não havendo uma preocupação quanto ao processo de produção gráfica que, por sua vez, pode ter se estendido por anos, quiçá milênios. O grande pecado dessa abordagem é isolar os registros rupestres de outros dados arqueológicos - tais como os vestígios líticos, as cerâmicas, os ornamentos, entre outros fragmentos de instrumentos e artefatos da cultura material e imaterial -, de modo que não seja possível propor reconstituições do contexto mais imediato de criação. Nas palavras de Martin, "a discussão em torno do registro rupestre, sem contexto arqueológico, não leva à conclusão arqueológica alguma” (MARTIN, 1993, p. 48).

Por mais discutíveis que as teorias de Worringer (1997) e Hauser (200o) sobre os registros rupestres possam ser - algo que será aprofundado mais adiante - elas não parecem configurar o alvo principal de ataque de Pessis, Martin e Guidon. Em um texto elaborado a seis mãos, o triunvirato da arqueologia piauiense endossa sua desconfiança contra práticas iconológicas que procuram desvendar o sentido oculto das imagens e seus significados universais. Diante desse excesso de subjetivismo interpretativo, as autoras reforçam, uma vez mais, a necessidade de se basear o exercício hermenêutico em métodos científicos comprováveis, incluindo as pinturas rupestres no conjunto dos artefatos investigados arqueologicamente. Em suas palavras, "os registros rupestres precisam ser tratados como mais um elemento da base de dados das pesquisas arqueológicas. Em consequência, devem também ser submetidos aos mesmos procedimentos de pesquisa aplicados a todos os vestígios arqueológicos" (PESSIS; MARTIN; GUIDON, 2014, p. 643).

Sendo assim, a abordagem arqueológica vem recuperar o contexto de descoberta dos vestígios, considerando as imagens rupestres enquanto produtos de uma "cadeia operacional, integrada pelas etapas do caminho técnico percorrido, da matéria ao produto. A maneira como estão articuladas as etapas das cadeias operacionais constituirá o perfil técnico e a base do conhecimento de uma comunidade cultural" (PESSIS, 2013, p. 66). Insere-se aqui a questão temporal ao se decompor os registros gráficos em fragmentos menores, vinculando-os - hipoteticamente, deve-se dizer - a instâncias cronoló- 
gicas distintas, definidas conforme alguns parâmetros, entre os quais se destacam os cenográficos, temáticos, técnicos ou de datação direta. Levando em conta a impossibilidade em se definir absolutamente a data e os significados dos registros rupestres, a abordagem arqueológica volta-se aos significantes enquanto "representações que envolveram posturas, gestos ou emblemas voluntariamente construídos" (PESSIS, 1993, p. 1011). Por mais que não procure definir os pretensos significados originais das imagens, esta abordagem busca circunscrever identidades gráficas de uma autoria coletiva e social, associada a traços culturais.

Guidon é, de fato, a pioneira nos esforços descritivos e classificatórios dos registros rupestres piauienses, conforme comprova exemplarmente o seu artigo A Arte Pré-histórica da Área Arqueológica de São Raimundo Nonato: Síntese de Dez anos, publicado em 1985. Mas é Pessis quem passa a considerar os registros rupestres enquanto representações gráficas de determinados grupos culturais, "declarando-se inimiga acérrima de tabelas e tábuas comparativas, e da segregação de painéis rupestres, os quais só poderão ser estudados cientificamente como um todo e dentro do contexto arqueológico" (MARTIN, 1993, p. 47). Sob a perspectiva da antropologia visual de Pessis, as imagens seriam indícios, visuais e técnicos, das unidades culturais que as realizaram, constituindo, pois, pistas do sistema social de seus autores. Assim, as imagens rupestres são uma importante via de acesso aos sistemas técnico e de apresentação gráfica de sociedades remotas. Essa abordagem é assim descrita por Martin, a partir de uma oposição de interesses entre a arqueologia e a história da arte:

A riqueza de dados que o estudo e a reflexão sobre a arte rupestre podem fornecer à História da Arte, não é fundamental aos arqueólogos. Cada vez mais precisamos pesquisar nas áreas arqueológicas, com alta concentração de registros rupestres, o contexto arqueológico que as acompanha, como forma de identificar os grupos étnicos aos quais pertencem. Somente depois dessa identificação, poderemos falar da arte rupestre deste ou daquele grupo, que viveu em determinado período de determinada área, em determinadas condições de sobrevivência, configurando-se, assim, a "história" de um grupo humano nos seus diferentes aspectos ecológicos, nos quais entrarão, também, os espirituais e técnicos, caso o registro arqueológico nos permita chegar ao seu mundo simbólico (MARTIN, 1993, p. 48). 
É bastante curiosa a dicotomia disciplinar proposta por Martin. Não que se discorde que a arqueologia e a história da arte, por mais próximas que possam ser, tenham interesses, instrumentos e métodos distintos. A indagação que ora se faz diz respeito não à abordagem arqueológica de viés antropológico das autoras aqui mencionadas, mas à história da arte a que se referem elas. Dois aspectos merecem destaque: o primeiro diz respeito à apropriação que as arqueólogas brasileiras realizam dos instrumentos analíticos mais convencionais da história da arte; além disso, nota-se a ausência de um embate mais explícito entre as interpretações dos vestígios rupestres realizadas pelos historiadores mais tradicionais - como Wilhelm Worringer, Arnold Hauser, Giulio Carlo Argan, Ernst Gombrich e também Georges Bataille - e os traços característicos da pintura rupestre piauiense, lacuna que justifica precisamente este ensaio.

Quando lê as publicações de divulgação científica sobre as pinturas rupestres piauienses, o especialista em história da arte logo nota a recorrência de alguns instrumentos analíticos tradicionais à área, com grande destaque para as noções de estilo, qualidade e beleza, sem desconsiderar, é claro, o próprio conceito de tradição, central ao exercício taxonômico de Guidon e seus pares. Não que o uso destes conceitos operacionais deva ser descartado como algo ultrapassado tendo em vista um novo momento teleológico e contemporâneo da arte. $\mathrm{O}$ que se estranha nessa utilização é que, no mesmo período em que ela estava sendo realizada, operava-se um questionamento radical da história da arte, conflito imposto pela criação artística surgida ao longo de todo século XX.

Ao que parece, o conceito de arte referido por Guidon e seus pares é aquele acadêmico, associado à beleza e à contemplação, algo que, no panorama mais hegemônico da arte moderna, já foi amplamente questionado a partir não tanto da dúvida de Cèzanne, mas da escolha de Duchamp. Há mais de um século, a discussão gira em torno de uma única indagação: isto é arte? Dessa forma, perguntar se algo é arte é uma tarefa epistemológica bastante frequente no circuito artístico contemporâneo, sendo essa discussão muito pertinente também aos vestígios rupestres piauienses (afinal de contas, não é apenas o urinol ou uma caixa de Brillo Box que podem suscitar este debate). Por mais absurdo que possa parecer aos olhos dos arqueólogos, é possível expor (e redesenhar) os limites, tanto da arte quanto da história da arte, ao confrontar estes enquadramentos com os vestígios rupestres milenares do Piauí. 
A inadequação entre as produções artísticas do século XX e a noção mais corrente de arte resvalou também no questionamento da própria história da arte enquanto ciência especializada na produção artística ocidental. É válido aqui recorrer à questão do estilo. Sem pretender esgotar esta discussão, considerem-se os ensaios elaborados no início da década de 60 por dois historiadores: Norma e Forma - as categorias estilísticas da história da arte e suas origens nos ideais renascentistas, texto baseado em uma conferência proferida por Gombrich em 1963 na Biblioteca Filosófica da Universidade de Turim, e Style, que Meyer Schapiro elabora um ano antes. Cerca de duas décadas antes de Rosalind Krauss ${ }^{3}$ desenvolver, em muitos dos ensaios compilados em The Originality of the Avant-Garde and other modernist myths, críticas pós-estruturalistas à noção do estilo tendo em vista o ethos da reprodutibilidade técnica, tanto Schapiro quanto Gombrich puseram-se a rever as origens, os usos e os processos de apropriação deste conceito ao longo da história da história da arte. Enquanto Gombrich investiga os percalços do exercício classificatório, expondo os riscos das categorias estilísticas transformarem-se em instrumentos normativos, Schapiro, por sua vez, enumera algumas fontes para a gênese de um estilo, tais como a função do artefato, a matéria de que ele é feito, o seu conteúdo e seu medium, concluindo, por fim, que "Não foi ainda elaborada uma teoria do estilo adequada aos problemas históricos e psicológicos"4 (SCHAPIRO, 1994, p. 100, tradução nossa). Se, ao final, o historiador norte-americano expõe a lacuna existente entre as formas artísticas e as formas psicossociais (algo que pode ser lido hoje como anunciando a antropologia das imagens, de Pessis ou de Belting, como se verá em seguida), logo no início Schapiro estabelece uma dicotomia entre o arqueólogo e o historiador que se aproxima, de certo modo, daquela proposta por Martin.

Seja como for, interessa reter aqui o seguinte: o processo de revisão e questionamento de conceitos como o de arte e de estilo parece ter desaguado em uma problematização radical da própria história da arte enquanto uma ciência europeia. Talvez, o melhor exemplo disso sejam os textos elaborados contemporaneamente na década de 1980 por Hans Belting e Arthur Danto onde os autores investigam o fim da (história da) arte. Mas, suas abordagens são opostas, visto que, conforme esclarece Lorenzo Mammì (2012, p. 25):

Danto tenta preservar a autonomia (a essência) da obra de arte em geral, e por isso renuncia a sua história e até à relação 
entre essência da obra e seu valor estético. Belting, ao contrário, tenta salvar a história da arte, e por isso renuncia ao caráter essencialmente autônomo da obra de arte.

O que Belting questiona é uma imagem da história da arte pretensamente universal, levando em consideração o divórcio entre as práticas artísticas do século XX e o enquadramento narrativo que se propunha a ordená-las autonomamente a partir dos estilos de época e de suas transformações internas. Em suas palavras,

o fim da história da arte não significa que a arte e a ciência da arte tenham alcançado o seu fim, mas registra o fato de que na arte, assim como no pensamento da história da arte, delineia-se o fim de uma tradição, que desde a modernidade se tornara o cânone na forma que nos foi confiada (BELTING, 2006, p. 23).

Ao tentar salvar a história da arte, Belting abre o enquadramento supostamente autônomo dessa disciplina rumo a uma orientação transdisciplinar compreendida enquanto uma antropologia das imagens. Neste âmbito, lhe interessa menos uma aproximação com a etnologia (algo que é visto no exercício arqueológico de Pessis) ${ }^{5}$ do que uma discussão em torno das recíprocas e infindáveis implicações triangulares entre corpo, imagem e medium. Para isso, Belting parte da investigação de Jean-Pierre Vernant em torno da distinção pré-clássica grega entre eidolon - i.e., imagem transitória que se dá em atividades mnemônicas, mentais e oníricas - e kolossos - imagem materializada em um medium determinado -, demonstrando as mútuas inter-relações entre as imagens físicas e mentais. Ora, o que é surpreendente neste redirecionamento da história da arte rumo a uma antropologia das imagens é sua estreita semelhança com a "virada antropológica”, se assim podemos designá-la, da abordagem arqueológica piauiense representada, sobretudo, pelas distintas - mas, de muitos modos, complementares - abordagens de Niède Guidon e Anne-Marie Pessis. Ou não haveria também uma implicação entre eidolon e kolossos quando Pessis afirma, em seu fenomenal estudo Imagens da Pré-História - os biomas e as sociedades humanas no Parque Nacional Serra da Capiva$r a$, que "a produção de imagens gráficas realiza-se de maneira análoga à produção de imagens mentais" (PESSIS, 2013, p. 87 )? Em suma, o princípio de exclusão que governou a dico- 
tomia entre arqueologia e história da arte - oposição exemplificada aqui nas vozes de Gabriela Martin e Meyer Schapiro - expõe-se ao limite de sua validade quando ambas as disciplinas abandonam seus redutos rumo a diálogos interdisciplinares mediados pela antropologia (em distintas vertentes, não se deve esquecer).

A suposta virada antropológica identificada no interior da abordagem arqueológica piauiense demonstra, com isso, que a própria divisão proposta por Pessis entre uma perspectiva pré-científica (ou clássica), de um lado, e outra científica (ou arqueológica), de outro, testemunha outra bipartição. Não se sabe ao certo se esta abordagem antropológica funcionaria como uma síntese dialética do subjetivismo interpretativo, de um lado, e do objetivismo científico, de outro. O que talvez se possa concluir é que este novo momento do pensamento arqueológico brasileiro tenta desviar-se das armadilhas de uma ou outra perspectiva, lidando com a "total fragmentação" (PESSIS, 2013, p. 94) do sentido do conjunto de figuras rupestres. E isto é fundamental (voltaremos a isto na conclusão).

Outro índice desta virada é a reavaliação do sistema taxonômico desenvolvido pela equipe de Guidon nos anos 70 e 8 o. Em um primeiro momento, a arqueóloga concebeu uma classificação preliminar contendo três ordens taxonômicas: as tradições, as subtradições e os estilos. Conforme esclarece a autora,

as tradições são definidas pelas classes de grafismos representados e pela proporção relativa que estas classes guardam entre si. Dentro das tradições pode-se, às vezes, distinguir-se sub-tradições segundo critérios ligados à diferenças na representação gráfica de um mesmo tema eà distribuição geográfica. A unidade de base, o estilo, é definida pela técnica de manufatura e pela apresentação gráfica (GUIDON, 1989, p. 6).

Das seis tradições definidas por Guidon, metade delas agrupa as pinturas e a outra metade as gravuras. Pode-se dizer que o sistema classificatório delineado parte de dois grandes horizontes culturais, a Tradição Nordeste (dominante no Piauí, em especial em São Raimundo Nonato, ${ }^{6}$ mas encontrada em outros estados, como Bahia, Rio Grande do Norte, Minas Gerais, Goiás, Sergipe e Pernambuco) e a Tradição Agreste (característica aos estados de Pernambuco e Paraíba)7. Supõe-se que a tradição Nordeste existiu por 6.000 anos entre 12.000 e 7.000-6.00o B.P. Nela, encontram-se representações figurativas de homens e animais, dominantes em relação à re- 
presentação de objetos, de figuras fitomorfas (isto é, de formas vegetais), bem como de grafismos puros, abstratos. As composições aqui encontradas exibem fundamentalmente os movimentos e as ações sociais dos povos pré-históricos, sejam elas sagradas - ligadas, portanto, aos mitos e às cerimônias ou profanas - vinculadas ao dia a dia. Por mais figurativas que sejam, elas não são realistas. Além disso, não são figuras estáticas: apresentam sempre movimento. Um exemplo pode ser esclarecedor: as figuras humanas não aparecem com braços para baixo (como nos retratos policiais), mas, na maioria das vezes, com braços ao alto ou arqueados. Ou ainda: os animais têm suas patas e pernas esticadas em "pleno vôo" - em uma semelhança distante com os cavalos pintados por Théodore Gericault em Corrida de Cavalos em Epsom (1821). Porém, se o contexto, o título e demais informações do quadro do pintor francês nos permitem compreender o significado das ações, ocorre algo diverso com as imagens rupestres, pois "a ação jamais é colocada em dúvida, mas a interpretação desta ação pode não ser claramente identificável face ao que os grafismos mostram" (GUIDON, 1985, p. 10).

Se a tradição Nordeste tem seu berço natal na Serra da Capivara, supõe-se que a tradição Agreste tenha se originado em Pernambuco, nas adjacências do rio São Francisco, o que explicaria a menor densidade de grafismos dessa linhagem no Piauí. Originalmente denominada de "tradição Castelo", a tradição Agreste esteve presente entre 10.500 e 4.000-3.00o B.P., tendo sido dominante apenas a partir de 6.ooo. Aqui, predominam as figuras humanas estáticas, por vezes representadas em ações de caça, havendo uma maior concentração de grafismos puros, sendo sua morfologia, sugere Guidon (1985), bastante distinta da tradição Nordeste. Há, contudo, algo interessante, na medida em que as duas tradições se misturam e se sobrepõem, assim como as demais tradições, em especial a denominada Geométrica. Somem-se a este conjunto as três tradições de gravuras - em geral compostas por grafismos puros e situadas próximas de reservatórios naturais de água denominadas de Itacoatiara de Leste, Itacoatiara de Oeste e Gongo. Não se esqueça ainda das subtradições contidas em algumas tradições, como, por exemplo, a subtradição Várzea Grande, incluída na Tradição Nordeste, onde se observa o estilo fundante, definido a partir de características técnicas, da Serra da Capivara.

No estilo Serra da Capivara, as figuras são, em grande parte, lisas, ou seja, inteiramente monocromáticas (em geral, o ver- 
melho resultante do óxido de ferro), sendo rara a presença de preenchimento com padrões geométricos ou de figuras vazias, só com as linhas de contorno. Especula-se que, neste estilo, os dedos foram utilizados para a representação visual (algo que também é sugerido por Argan para as pinturas da zona franco-cantábrica), sendo também possível o uso de instrumentos mais sutis, como os espinhos de cactos, para os desenhos constituídos por linhas mais finas. Guidon observa uma dominância óptica das figuras animais em relação às demais figuras, pois:

as relações de tamanho entre as figuras humanas e animais, mesmo nos grafismos de ação onde os dois grupos de grafismos aparecem associados, mostram que o homem é sempre representado com um tamanho inferior ao dos animais. Este fato [do estilo Serra da Capivara] vai se repetir em outros estilos, salvo em algumas exceções no estilo Serra Branca (GUIDON, 1985, p. 21).

Talvez, aquilo que diferencie mais o estilo Serra Branca seja a presença de padrões geométricos preenchendo as figuras antropomorfas retangulares. Ao lado dele, há ainda o Complexo Serra Talhada, marcado por figuras miniaturizadas diferenciadas assim por Guidon (1985, p. 25):

No estilo Serra da Capivara, a técnica de preenchimento por pintura lisa é preponderante; no estilo Serra Branca domina o preenchimento por traçado geométrico. No complexo Serra Talhada, ao contrário, encontram-se além de inúmeras figuras que possuem estas duas técnicas, figuras nas quais uma parte do corpo é preenchida por pintura lisa e uma faixa, entre o centro pintado e o contorno, à vazia. Outros grafismos são preenchidos por pontos ou traços.

Este breve panorama nos permite constatar a extrema fertilidade do exercício taxonômico dos registros rupestres. Apesar disso, há que se dizer que o sistema classificatório estabelecido originalmente será parcialmente deixado de lado. Esse movimento se deve em parte à própria desconfiança das autoras, expressa recentemente do seguinte modo:

Preocupa-nos a banalização nas classificações, as quais iniciadas como preliminares ou provisórias, passaram a ser definitivas à força de serem repetidas. Chega-se, em casos extremos, a um maniqueísmo classificatório reducionista: o que 
não pertence à tradição Nordeste passa a ser representativo da tradição Agreste (GUIDON; MARTIN, 2010, p. 15).

No que concerne às tradições de gravuras, as autoras afirmam que "na hora de possíveis classificações, o termo 'tradição itacoatiara' fica fora de lugar e passa a não explicar nada. Tradição Itacoatiara seria hoje o mesmo que dizer 'tradição de gravuras"' (GUIDON; MARTIN, 2010, p. 17-18). Para evitar a passagem da forma à norma que caracteriza o exercício classificatório, optou-se por apenas tangenciar essas taxonomias. Há também outros motivos que nos levam a descartar parcialmente o sistema taxonômico inicial. De certo modo, a desobediência aos parâmetros classificatórios vigentes parte, de um lado, à consideração das pinturas rupestres piauienses de um modo global, notando, portanto, mais semelhanças do que diferenças. Essa visão de conjunto se justifica, sobretudo, quando se leva em consideração o debate, especificamente no terreno da história da arte, em torno das pinturas rupestres. A atenção dedicada a essas práticas pictóricas por pensadores como Argan, Hauser, Gombrich, Bataille e Worringer focaliza inequivocamente os registros rupestres europeus, não havendo aí espaço para os achados brasileiros. É possível escusá-los com o fato nada trivial de as descobertas brasileiras serem posteriores à grande parte desses estudos. Ainda assim, a ausência se revela sintomática e é a partir dela que se desenrola esta especulação a partir de agora. O propósito não é inserir as imagens piauienses no enquadramento historiográfico e crítico tradicional, mas observar como este último se transforma quando consideradas estas imagens. Assim, não se pretende aqui discutir tecnicamente origens e fins, materiais e solos algo que já está sendo realizado exemplarmente pelas equipes arqueológicas do Nordeste brasileiro -, mas confrontar as imagens rupestres brasileiras e o enquadramento corrente sobre o tema nos anais da história da arte, a fim de mostrar as inadequações daí resultantes.

Não se trata, portanto, de um exercício interpretativo, do qual Guidon, Martin e Pessis nutrem plena desconfiança. Não interessa aqui identificar mensagens ocultas, significados universais, narrativas globais ou coisas do gênero. Do ponto de vista metodológico, posicionamo-nos também "against interpretation", como postula Susan Sontag, buscando uma erótica da arte a partir do confronto direto com alguns sítios arqueológicos do Parque Nacional Serra da Capivara. Levando em consideração, sobretudo, as evidências gráficas e anônimas 
das pinturas rupestres piauienses, pretende-se recuperar duas dicotomias recorrentes no âmbito da história da arte - quais sejam, os pares geometrismo-naturalismo e humano-animal - a fim de revelar os limites de suas aplicações. Acredita-se, com isso, que este também seja um exercício crítico em relação ao enquadramento mais convencional da história da arte, sendo necessário forjar novos pares conceituais adequados aos vestígios rupestres americanos. Busca-se, assim, acessar a história da arte por meio não da apropriação confirmatória de seus instrumentos - os conceitos problemáticos de arte ou de estilo, por exemplo - mas do embate entre a leitura de historiadores para as cavernas europeias e os vestígios rupestres piauienses.

\section{Naturalismo e geometrismo nas pinturas rupestres piauienses}

Considere as duas imagens abaixo:

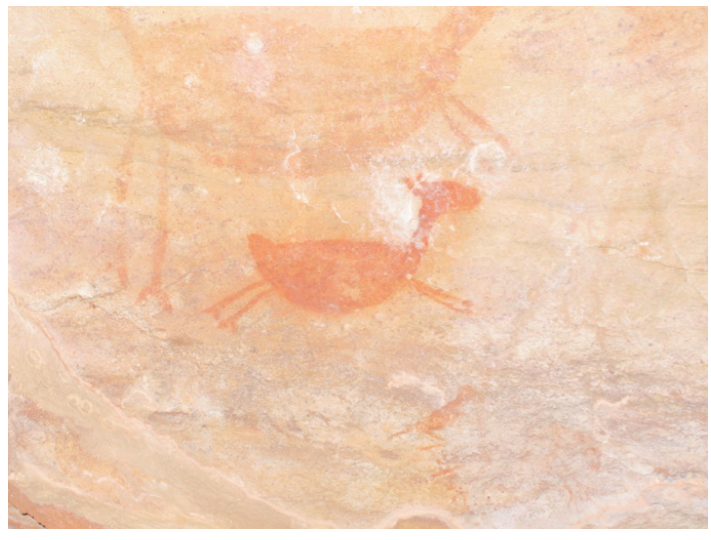

(a)

É possível reconhecer o que ambas as imagens representam devido à presença respectiva de características estruturais essenciais: um animal e um homem. Contudo, a primeira figura, despida de fisionomia e particularidade, se destaca do fundo enquanto unidade indivisa, formando um todo cromático. Já a espécie humana é representada a partir de um longo retângulo disposto na vertical, no interior do qual são dispostos alguns parâmetros geométricos que conferem especificidade à figura representada. Os padrões grá-
Fotografia 1 - Vestígios Rupestres da Serra da Capivara

Legenda: (a) Cervídeo; (b) Homem inscritos na Toca do Boqueirão da Pedra Furada Fonte: Ícaro Lira (2017). 
ficos encontrados no corpo humano, supomos, teriam uma função próxima da arte cadiuéu, conforme a leitura proposta por Claude Lévi-Strauss, operando "a passagem da natureza à cultura, do animal 'estúpido' ao homem civilizado" (LEVI-STRAUSS, 1996, p. 183). Isto é, seja pintura corporal, seja ornamento, os geometrismos encontrados na espécie humana indicariam sua distância frente à espécie animal, cuja representação seria plenamente preenchida de uma única cor. Dito isto, poderíamos nos apressar nas conclusões e induzir que a representação respectiva às figuras humanas e animais, apesar de partir de elementos geométricos determinados - os retângulos verticais e as elipses horizontais - são bastante distintas, reforçando, portanto, uma das dicotomias fundantes da Antropologia, qual seja, a oposição entre Natureza e Cultura.

Esta cisão também endossaria, por vias tortas, a leitura que Georges Bataille realiza das pinturas rupestres, primeiro em sua review do livro L'Art Primitif, de Georges-Henri Luquet, publicada na DOCUMENTS n. 7 (1930) com desenhos de crianças (Lili Masson, filha de André Masson, então com nove anos, e outras ilustrações de crianças etíopes retiradas do estudo de Marcel Griaule), depois em O Nascimento da Arte. No livro resenhado por Bataille, Luquet traça uma linha evolutiva da arte a partir das pinturas rupestres sob duas hipóteses: de que tais imagens não apresentariam intenções figurativas e que elas poderiam ser comparadas aos desenhos infantis, apresentando os mesmos atributos. Eis, pois, uma leitura cronológica, que parte de um esquematismo ao figurativismo, contradizendo as próprias imagens encontradas nas cavernas pré-históricas. Posição contrária, mas complementar, é tomada por Arnold Hauser em História social da arte e da cultura, para quem "o naturalismo faz jus à reivindicação de prioridade, pelo que se torna cada vez mais difícil sustentar a teoria do primado de uma arte afastada da vida e da natureza" (HAUSER, 200o, p. 1), descartando o autor "qualquer paralelismo entre a arte pré-histórica e a arte infantil ou a arte da maioria das mais recentes raças primitivas" (HAUSER, 2000 , p. 2). Apesar de inverter a ordem de precedência, Hauser mantém os polos opositivos, propondo uma equivalência entre as formas sociais e as formas artísticas. Assim, à transição do paleolítico ao neolítico - isto é, de uma economia de exploração a uma economia de produção - corresponderia "a primeira mudança estilística de toda a história da arte" (HAUSER, 2000, p. 9) do naturalismo ao geometrismo. 
Wilhelm Worringer (1997), por sua vez, em seu livro Abstract and Empathy, reforça a antítese entre o naturalismo (que ele difere da imitação de um mero objeto) e o estilo (sua denominação para o geometrismo) compreendendo ambos enquanto polos de um sistema estético cujo funcionamento é dado pelo que Alois Riegl denominou de Kunstwollen - will to form, ou, conforme propõe Germain Bazin (1989), uma pulsão artística. Há duas possibilidades para essa pulsão artística conforme a relação psíquica que o ser humano mantém com o meio circundante: caso seja atraído pelo espaço, havendo aí uma relação de confiança e segurança, o artista desenvolve uma empatia que desemboca no naturalismo. Caso contrário, havendo uma perplexidade do artista frente ao mundo, este indivíduo busca refúgio na abstração, gerando, por consequência, a estilização do mundo estreitamente vinculada à valorização do plano e à supressão da profundidade. Em suma,

Em cada momento histórico, a arte responde propriamente a necessidades psíquicas profundas, mas não apenas o impulso de pura imitação, o prazer lúdico de copiar o modelo natural [...] Enquanto que o desejo de empatia nasce de uma feliz e panteística relação de confiança entre o homem e os fenômenos do mundo exterior, o desejo de abstração resulta de um maior desconforto interior provocado no homem pelos fenômenos do mundo exterior (WORRINGER, 1997, p. 12-15, tradução nossa).

Considerando os esquemas propostos por Luquet, Worringer e Hauser, nota-se que os autores não hesitam em vincular fortemente o geometrismo e o naturalismo a fases distintas de formação individual, psíquica e social. Em vez de distribuir o par opositivo diacronicamente, Bataille o dispõe sincronicamente, observando métodos distintos de representação conforme os objetos representados. Quanto a isso, é preciso notar que todo o esforço de Bataille se dirige menos a Luquet do que as "dualidades não dialéticas" e teleológicas de Ernest Hamy (DIDI-HUBERMAN, 2015, p. 280) das quais Luquet parte, mas não resolve. Bataille se apropria da oposição de Luquet entre um realismo visual e um realismo intelectual, sendo o primeiro associado à observação dos elementos do modelo retratado e o segundo associado à compreensão da imagem, já livre de qualquer coerção óptica. "Alguma coisa, em tudo isso," observa Georges Didi-Huberman (2015, p. 283), 
o incomodava no entanto. A oposição formal - e nisso interessante - dos dois "realismos" segundo Luquet não chegava, aos olhos de Bataille, a refutar inteiramente a hierarquia e o sentido teleológico contidos na separação entre uma arte "primitiva" (ou infantil) e uma arte "civilizada" (ou adulta). Essa observação [...] permanece [...] aquém de uma compreensão dialética das formas. O redator de DOCUMENTS faz aqui uma observação que fornecerá, mais tarde, toda a ossatura teórica do livro sobre Lascaux: a de que a arte pré-histórica já tinha integrado ou confrontado em si mesma elementos característicos do "realismo intelectual" (especialmente nas representações antropomorfas, todas mais ou menos "decompostas"), mas também elementos indubitáveis do "realismo visual" (sobretudo nas representações animais investidas frequentemente de uma competência mimética estupeficante).

A "infância da arte" seria, com isso, já dialética, a partir do movimento entre os dois realismos dispostos não diacronicamente, mas simultaneamente. Meyer Schapiro (1994) - que menciona também a divisão proposta por Emanuel Löwy entre uma "conceptual representation" e uma "perspective representation" que se assemelha bastante à oposição de Luquet - é da mesma opinião ao afirmar, em "Style", o seguinte:

As formas geométricas e naturalistas podem surgir independentemente em diferentes contextos e coexistir no interior de uma mesma cultura. A experiência da arte dos últimos cinquenta anos sugere ainda que o grau de naturalismo na arte não é uma indicação segura do nível tecnológico ou intelectual de uma dada cultura (SCHAPIRO, 1994, p. 75-76, tradução nossa).

Considerando este debate em torno da dicotomia entre um realismo visual, de um lado, e um realismo intelectual, de outro lado, dispostos ora diacronicamente, ora sincronicamente, poder-se-ia argumentar que as duas imagens encontradas no Piauí indicariam, seguindo a observação tenaz de Bataille, modos distintos de se representar o ser humano e o animal. Contudo, essa conclusão nada mais seria do que uma ficção, uma vez que as duas figuras aqui comentadas filiam-se a concepções estilísticas distintas - o estilo Serra Branca e o estilo Serra da Capivara, respectivamente - sendo possível encontrar tanto animais ornados de padrões geométricos quanto seres humanos monocromáticos: 


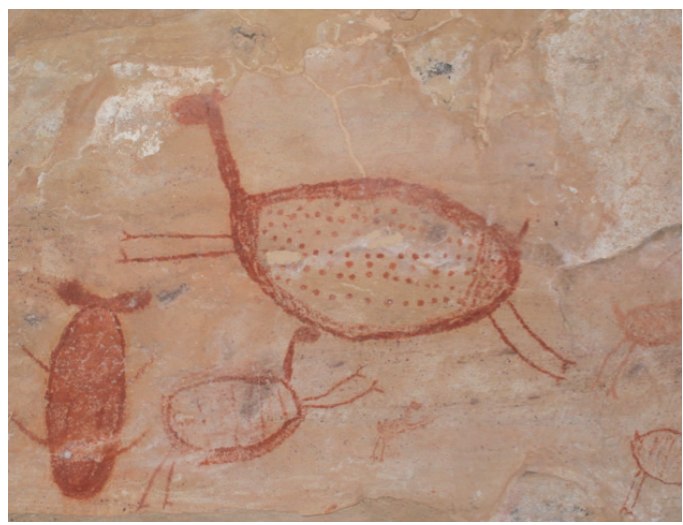

(a)

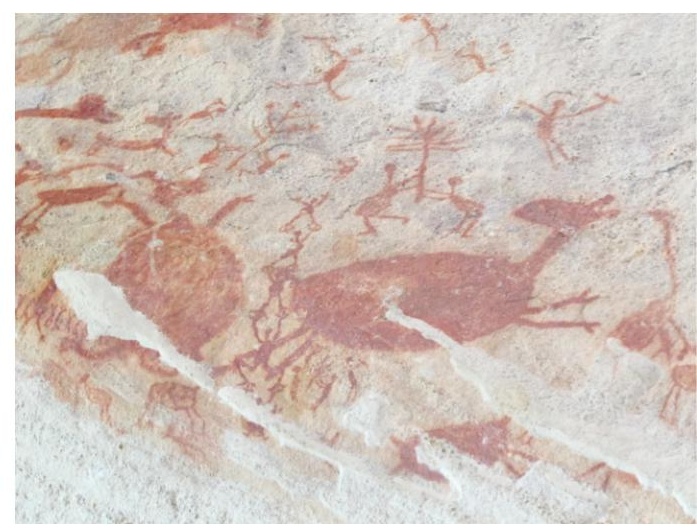

(b)

Se não se pode então estabelecer nem uma dicotomia diacrônica - que corresponda a estágios distintos da cruzada civilizatória - nem uma oposição sincrônica - que demonstre métodos representacionais específicos aos objetos representados - de que maneira a oposição entre o naturalismo e o geometrismo ainda poderia ser útil na observação das pinturas rupestres piauienses? Uma vereda possível seria aquela que associaria respectivamente os dois tipos de realismo, visual e intelectual, aos dois estilos, Serra da Capivara e Serra Branca. Assim, esforçaríamos por depreender de cada caso traços que comprovem a sua adesão ao naturalismo e ao geometrismo. Considere-se, contudo, as imagens: não há, arrisca-se aqui a dizer, naturalismo possível nem um estilo nem em outro. Dito de outro modo: o reconhecimento das figuras resulta da economia visual que atravessa ambos os estilos, mesmo que haja uma imagem plenamente preenchida ou geometricamente ornada. Caso essa hipótese de leitura seja válida, pode-se dizer que as pinturas rupestres piauienses possuem graus variados de esquematismo sem que, ao contrário do que ocorre com as imagens da zona franco-cantábrica, nenhuma delas se apresente ao olhar sob os auspícios de um naturalismo surpreendente.

Considerando, pois, a dicotomia entre o naturalismo e o geometrismo, é possível afirmar que as imagens piauienses não são nem absolutamente naturalistas, nem unicamente geométricas. Elas não se encaixam, portanto, no esquema teórico mais corrente, no âmbito da história da arte, sobre as 
pinturas rupestres representado aqui pelas teorias de Worringer, Hauser, Luquet e Bataille. Se assim é, o que então estas imagens indicariam?
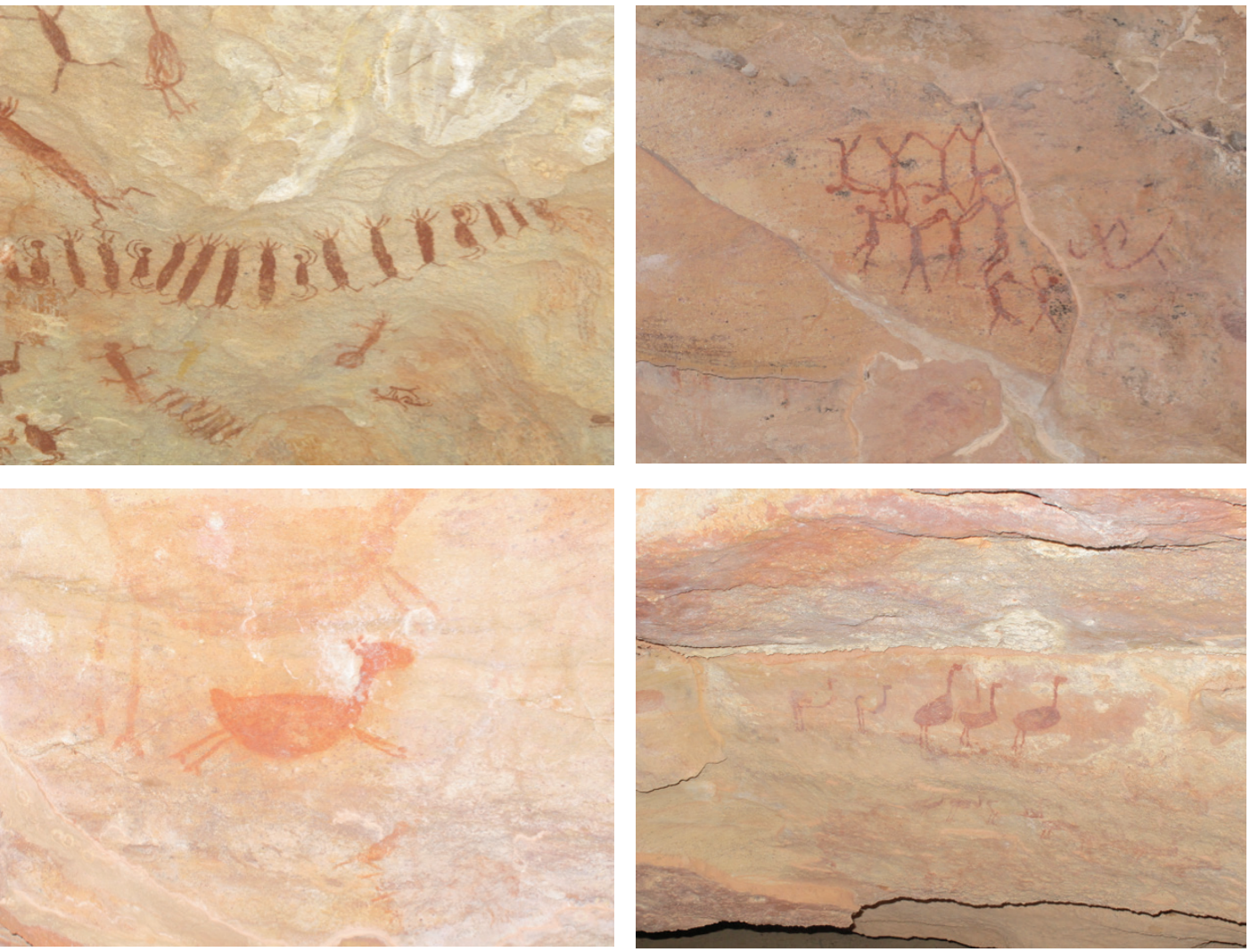

(a) (c)

(b)(d)

Figura 3: (a); (b); (c); (d) Imagens Rupestres encontradas nos sítios arqueológicos do Parque Nacional Serra da Capivara

Fonte: Ícaro Lira (2017).
Ao passear por alguns dos circuitos que constituem o Parque Nacional Serra da Capivara, o visitante logo nota um fato surpreendente: a diversidade e a facilidade de identificação de algumas figuras representadas, em especial os homens e os animais. De fato, não é um grande desafio constatar a economia de traços que caracteriza os métodos representativos dessa região. Considerando especificamente algumas imagens do estilo Serra da Capivara, nota-se que uma pontual adição (ou subtração) na imagem altera em absoluto a espécie representada. Assim, focalizando o mundo ficcional das espécies representadas, o homem não é, por sua natureza representativa, distinto de um 
cervídeo nem de uma ema. Sintetizando de modo brutal, poder-se-ia dizer que uma espécie se diferencia das demais devido a traços pontuais (adicionados ou subtraídos): uma ema é um cervídeo sem as duas patas dianteiras nem as orelhas, com pescoço mais alongado e pés tripartidos. Inversamente, um cervídeo é uma ema com patas dianteiras, pescoço menos alongado e pés bipartidos. Por vezes, o homem e o animal também apresentam fantásticas similaridades dentro desta economia visual. Por vezes, a conjunção de seres humanos compõe malhas geométricas. Por vezes, uma fila de bastonetes se transmuta em uma fila de homens (ou vice-versa). Descartando as interpretações universais, as evidências visuais nos permitem conjecturar haver aí uma continuidade forte entre pintura e escritura, sendo estes registros rupestres uma espécie de pictograma, cujos código e finalidade se perderam. Desse modo, observa-se, de maneira relativamente fácil, espécies absolutamente distintas como uma ema e um cervídeo - cuja distinção é, contudo, dada por meio de alterações precisas e pontuais, a exemplo do traço descendente que difere o R do $\mathrm{P}$ e que, de certa forma, sintetiza todo o sistema linguístico estrutural. Evidentemente, não se quer aqui fomentar a ideia de se reconstituir tal sistema nem sugerir, conforme Argan (2003), que os signos, por sua estabilidade, indicariam uma distância do naturalismo paleolítico rumo à abstração neolítica (pois o movimento é um elemento fundamental nas pinturas piauienses, casado, surpreendentemente, com a economia de traços), mas de simplesmente reconhecer, com Gombrich (2011, p. 53), que "imagens e letras são na verdade parentes consanguíneos".

$\mathrm{O}$ parentesco entre imagens e textos nas escrituras piauienses, aliado à reversibilidade das espécies resultante do acréscimo (ou a subtração) de elementos visuais pontuais e também ao seu caráter vestigial as situa surpreendentemente no campo das cosmovisões indígenas. De modo mais cirúrgico, o jogo metamórfico entre as espécies confere um estatuto especial a estas imagens, nos permitindo trazer ao debate o devir-animal e a "pressuposição antropomórfica do mundo indígena” (VIVEIROS DE CASTRO, 2015, p. 54), visto que há em muitas mitologias indígenas (como entre os Tupinambá, os Yanomami e os Kuikuro, para citar apenas alguns exemplos) uma dinâmica incessante entre formas humanas e não -humanas postas não de modo externo a cada ser existente, mas em seu interior mesmo. Em suma, o perspectivismo e o multinaturalismo ameríndios funcionariam aqui como poderosas chaves de leitura às pinturas rupestres. 
Caso esta hipótese de leitura seja válida, não fazemos outra coisa a não ser reconhecer nessas imagens a sua qualidade antinarcísica, o outro de nós mesmos. Pois, de um lado, o perspectivismo indígena desvia-se dos etnocentrismos antropológicos por meio de uma contra-antropologia baseada na experimentação do pensamento ameríndio. De outro lado, as imagens são apenas vestígios: trata-se de uma escritura não fonética que, descartando a tendência logocêntrica da linguagem, afirma não o significado oculto, mas o traço ele mesmo que identifica seu autor cultural e diferencialmente, mantendo-o, todavia, no anonimato. Tudo soa então como se, ao invés de estar diante do espelho para contemplar sua própria imagem, o artista pré-histórico fragmentasse essa superfície por meio de suas inscrições, deixando, pois, seu traço refratado indicando uma presença ausente.

NOTAS

1 A área arqueológica não se limita ao município de São Raimundo Nonato, devendo-se incluir aí São João do Piauí, Canto do Buriti, Anísio de Abreu, Coronel José Dias e Caracol.

2 "O conhecimento do que aconteceu antes da história oficial da colonização portuguesa está cheio de lacunas [...] Qualquer reconstituição a partir de fragmentos arqueológicos está acompanhada de um certo grau de imprecisão, dependendo da quantidade e do estado de conservação desses vestígios", afirma Anne-Marie Pessis (2006, p. 196).

3 Soa um pouco arbitrário mencionar o nome de Rosalind Krauss em uma discussão sobre a arqueologia brasileira. Talvez, o fato de André Leroi-Gourhan ter sido professor tanto de Niède Guidon quanto de Annette Michelson - fundadora, junto com Krauss, da October - amenize esta estranheza. É Michelson quem, na edição n. 37 da October contendo dois textos de Leroi-Gourhan ao lado de ensaios de historiadores questionando o mito da originalidade moderna, afirma que "Ele foi, nas últimas quatro décadas, a maior força de renovação de nosso entendimento sobre a arte do homem pré-histórico"» (MICHELSON, 1986, p. 3, tradução nossa). Assim como em seu ensaio "Antivision", publicado em 1986 na edição da October dedicada a Bataille, Krauss retoma, em The Optical Unconscious, esta questão, trazendo ao debate as interpretações de Leroi-Gourhan (1911-86) e Henri Breuil (1877-1961), cujos métodos de investigação são antitéticos: conforme pontua Michelson, a importância do arqueólogo consiste justamente " Na substituição do método estratigráfico prevalecente no tempo de Boucher de Perthes e epitomizado pela obra do celebrado predecessor de Leroi-Gourhan, o Abade Breuil, pelo método planográfico de escavação"9 (MICHELSON, 1986, p. 4, tradução nossa). Aos métodos distintos correspondem também interpretações diferentes. De um lado, a tese de Breuil tem como premissa o impulso mimético do homem: até mesmo a ausência das falanges nas mãos neolíticas confirma esse impulso, indicando rituais como a circuncisão. Assim, a perfeição ou as falhas da imagem são meros reflexos das características de seu criador. De outro lado, Leroi-Gourhan - discípulo dos sociólogos franceses Marcel Mauss e Marcel Granet - desenvolve uma interpretação semiótica das imagens rupestres, considerando-as mitogramas, isto é, signos linguísticos a serviço do mito. A interpretação de Bataille não é subsumida nem na teoria de Breuil nem da de Leroi-Gourhan. Os impulsos para o desenho são sádicos, envolvendo aí uma outra abordagem da mutilação que não a de Breuil: "Se 'primitivo' é compreendido sob o modelo da criança, o nascimento da arte é também um ato de desfiguração, de automutilação, 
do dígito removido. Não para produzir as formas da linguagem: macho/ fêmea; mas para produzir a ausência de diferença: informe. Este impulso à auto-desfiguração, este anti-narcisismo, surge nas representações hediondas da humanidade encontradas nas cavernas. Na mesma parede onde estão registrados um nobre bisão e um poderoso mamute, encontra-se humanos apenas grotescos. Esse impulso não é para a representação, ele diz, mas para a alteração" ${ }^{\circ}$ (KRAUSS, 1994, p. 152, tradução nossa). Á teoria de Bataille sobre as imagens pré-históricas encontra-se em seu livro $O$ nascimento $d a$ arte e também inclui a ação do grafite que é utilizada por Krauss para analisar as obras de Cy Twombly e Joan Miró.

4 Texto original em inglês.

5 A etnoarqueologia pode ser observada, por exemplo, no livro de Pessis Imagens da Pré-História - os biomas e as sociedades humanas no Parque Nacional Serra da Capivara - onde o primeiro capítulo é reservado à questão indígena. De modo mais preciso, Marcélia Marques desenvolve hipóteses, em seu livro Materiais e Saber na Arte Rupestre, a respeito da técnica de composição do pigmento pictórico pré-histórico a partir das práticas ainda encontradas entre as índias Tremembé: "No plano da analogia etnológica e arqueológica, o processo de decantação se revela esclarecedor para pensarmos o modo em que as tintas pré-históricas foram confeccionadas" (MARQUES, 2009, p. 138), ressalta a autora.

6 As especulações ora em curso são motivadas, sobretudo, pela observação direta e imediata de alguns sítios arqueológicos desta tradição presentes no Parque Nacional da Serra da Capivara. Agradeço a Ícaro Lira e ao guia Mario Filho pela companhia e pelo debate durante a visita em janeiro de 2017. Agradeço também a Bruno Primo e à Fernanda Achete pela companhia durante a visita à Tanzânia em 2013-14.

7 Mais recentemente, a descoberta dos registros rupestres na Serra das Confusões, no Piauí, embaralhou este sistema classificatório, uma vez que as características visuais das imagens diferem substancialmente da Tradição Nordeste.

8 Texto original em inglês.

9 Texto original em inglês.

10 Texto original em inglês.

\section{Referências}

ARGAN, Guilio Carlo. História da Arte Italiana. Da Antiguidade a Duccio. São Paulo: Cosac Naify, 2003. (Volume 1).

BATAILLE, Georges. O Nascimento da Arte. Lisboa: Sistema Solar, 2015.

BAZIN, Germain. História da história da arte. São Paulo: Martins Fontes, 1989.

BELTING, Hans. O fim da história da arte: uma revisão dez anos depois. São Paulo: Cosac Naify, 2006. . Por uma antropologia da imagem. Concinnitas - Revista do Instituto de Artes da UERJ, ano 6, v. 1, n. 8, jul. 2005. BELL, Clive. Art. New York: Frederick A. Stockes Company Publishers, 1914.

BRITO, Ronaldo; FLÓRIDO, Marisa. Há um colapso e um re- 
arranjo entre imagens e relatos, entre o expor e o significar. Arte \& Ensaios, n. 27, dez. 2013.

BUCHLOH, Benjamin. The whole earth show: an interview with Jean-Hubert Martin. In: Making Art Global (Part 2) 'Magiciens de la Terre' 1989. Londres: Afterall Books, 2013. DERRIDA, Jacques. Gramatologia. São Paulo: Perspectiva, 2013.

DIDI-HUBERMAN, Georges. A semelhança informe ou o gaio saber visual segundo Georges Bataille. Rio de Janeiro: Contraponto, 2015.

FORSSMANN, Alec. Descubren más de 400 pisadas de 'Homo sapiens' junto a un volcán de Tanzania.National Geographic España. 2016. Disponível em: <http://www.nationalgeographic.com.es/historia/actualidad/descubren-mas-400-pisadas-homo-sapiens-junto-volcan-tanzania_10779>. Acesso em: 10 ago. 2017.

FRIQUES, Manoel Silvestre. Da pintura histórica à bienal histórica: autonomia, curadoria e bienalização. Revista Pós, Belo Horizonte, v. 6, n. 12, p. 287 - 308, nov.2016.

GOMBRICH, Ernst Hans. Norma e Forma. São Paulo: Martins Fontes, 1990.

. A história da arte. Rio de Janeiro: LTC, 2011.

GUIDON, Niède. A arte pré-histórica de São Raimundo Nonato: síntese de dez anos de pesquisa. Clio, série Arqueológica, v.2, p.3-90, 1985 .

- Tradições Rupestres da Área arqueológica de São Raimundo Nonato, Piauí, Brasil. Clio, Série Arqueológica, n. 5,1989 .

; MARTIN, Gabriela. A onça e os orantes: uma revisão das classificações tradicionais dos registros rupestres do NE do Brasil. Clio, série Arqueológica, v. 25, 2010. (Este texto é uma variação daquele escrito a seis mãos e que li no livro).

HAUSER, Arnold. História Social da Arte e da Literatura. São Paulo: Martins Fontes, 2000.

KOPENAWA, Davi; ALBERT, Bruce. A queda do céu: palavras de um xamã Yanomami. São Paulo: Cia das letras, 2015.

KRAUSS, Rosalind. The Optical Unconscious. Massachusetts: MIT Press, 1994.

The originality of the avant-garde and other modernist myths. Massachusetts: MIT Press, 1986.

LÉVI-STRAUSS, Claude. Tristes trópicos. São Paulo: Companhia das Letras, 1996.

MAMMİ, Lorenzo. O que resta: arte e crítica de arte. São Paulo: Cia das Letras, 2012.

MARQUES, Marcélia. Materiais e Saber na Arte Rupestre. For- 
taleza: Museu do Ceará, 2009.

MARTIN, Gabriela. Arte Rupestre e Registro Arqueológico no Nordeste do Brasil. Clio, série Arqueológica, v. 9, 1993.

Pré-História do Nordeste: Pesquisas e Pesquisadores. Clio, série Arqueológica, v. 12, 1997.

; ASON, Irma. A tradição Nordeste na Arte Rupestre do Brasil. Clio, série Arqueológica, v. 14, 2000.

MICHELSON, Annette. In Praise of Horizontality: André Leroi-Gourhan 1911-1986. The MIT Press, v. 37, p. 3-5, out. 1986,.

NAVES, Rodrigo. A forma difícil. São Paulo: Editoria Ática, 1996.

. O vento e o moinho: ensaios sobre arte moderna e contemporânea. São Paulo: Cia das Letras, 2007.

PEDROSA, Mario; MAMMI, Lorenzo (Org.). Arte. Ensaios: Mário Pedrosa. São Paulo: Cosac Naify, 2015.

PESSIS, Anne-Marie. Imagens da pré-história. Parque Nacional Serra da Capivara: FUNDHAM Ed., 2013.

Registros Rupestres, perfil gráfico e grupo social. Clio, Série Arqueológica, n. 9, 1993.

; MARTIN, Gabriela; GUIDON, Niède. Da confiabilidade dos registros gráficos rupestres da pré-história. In:

(Org.). Os biomas e as sociedades humanas na pré-história da região do Parque Nacional Serra da Capivara, Brasil. São Paulo: A\&A Comunicação, 2014. (volume II A e B).

et al. Arqueologia Pré-Histórica do Brasil: Textos de divulgação Científica. Clio, série Arqueológica, n. 21, v. 02, 2006.

SCHAPIRO, Meyer. Style. In: Theory and Philosophy of Art: Style, Artist and Society. New York: George Braziller, 1994. (Volume IV)

SCOVINO, Felipe. Ser curador hoje no Brasil. Revista Poiésis, n. 26, p. 35-40, dez. 2015.

SONTAG, Susan. Against Interpretation and Other Essays. Nova York: Farrar, Straus and Giroux: Picador, 2001.

VENANCIO FILHO, Paulo. A presença da arte. São Paulo: Cosac Naify, 2013.

VIVEIROS DE CASTRO, Eduardo. Metafísicas Canibais. São Paulo: Cosac Naify, 2015.

WORRINGER, Wilhelm. Abstraction and Empathy. Introduction by Hilton Kramer. Chicago, Elephant Paperback, 1997. 
Recebido em: 09/07/2017

Aprovado em: 25/10/2017

\section{MANOEL SILVESTRE FRIQUES \\ manoel.friques@gmail.com}

Escola de Engenharia de Produção, UNIRIO, Rio de Janeiro, Rio de Janeiro, Brasil. Manoel Silvestre Friques é Teórico do Teatro (UNIRIO) e Engenheiro de Produção (UFRJ). Doutor em História no Programa de História Social da PUC-Rio, é Mestre em Artes Cênicas pela UNIRIO. Professor da Escola de Engenharia de Produção da UNIRIO, deu aulas, entre 2008 e 2013, nos cursos de Design de Moda e Artes da Faculdade SENAI Cetiqt. Publicou o livro de críticas Seis Chaves (EAV, 2012) e ensaios nas revistas Concinittas, Poeisis, Arte \& Ensaios, Percevejo, Urdimento, E-compós, dentre outras. Dentre suas últimas curadorias destacam-se "Bailado no Tempo", individual de Juana Amorim (Centro de Justiça Federal, 2017), "Lúmens" (Furnas Espaço Cultural), "Incorpóreo" (Centro de Justiça Federal), ambas individuais de João Penoni em 2013; "Brazo de Monte", exposição individual de Andrés Boero Madrid, no Uruguai em 2014; e as exposições coletivas "Coisas Vistas Aqui e Ali, Sem Óculos" e "Curadoria Operária” (ambas no Espaço Cultural Sergio Porto, 2014). 